\title{
Isolation and identification of Dichelobacter nodosus and Fusobacterium necrophorum using the polymerase chain reaction method in sheep with footrot
}

\author{
Ediz Kagan Ozgen ${ }^{1}$, Seyda Cengiz ${ }^{2}$, Mustafa Ulucan ${ }^{1}$, Zafer Okumus ${ }^{3}$, Asli Kortel ${ }^{1}$, \\ Huseyin Erdem ${ }^{1}$, Huseyin Gurkan Sarac ${ }^{1}$
}

\begin{abstract}
${ }^{1}$ Erzurum Veterinary Control Institute, Ministry of Food, Agriculture and Livestock, Erzurum, Turkey
${ }^{2}$ Atatürk University, Faculty of Veterinary Medicine, Department of Microbiology, ${ }^{3}$ Department of Surgery, Erzurum, Turkey
\end{abstract}

Received June 25, 2014

Accepted February 25, 2015

\begin{abstract}
Footrot is an important infectious disease of small ruminants leading to severe economical losses. The aim of the present study was to determine isolation and identification rates of Dichelobacter nodosus and Fusobacterium necrophorum in the culture techniques and reveal the specificity and sensitivity of the culture technique based on the polymerase chain reaction (PCR) method in sheep with footrot. Dry swabs and swabs with Amies medium from 83 sheep were subjected to PCR and culture analyses. In dry swabs, 4 samples were positive for F. necrophorum and all were negative for D. nodosus. Colonies in Eugon and Fusobacterium selective agars from swabs with Amies medium were evaluated. Polymerase chain reaction analysis was conducted on macroscopically and microscopically unidentified samples. The positivity rate was $55.4 \%$ for D. nodosus and $69.8 \%$ for F. necrophorum in cultures from Fusobacterium selective agars. The positivity rate for $D$. nodosus in Fusobacterium selective agars was higher than that in Eugon agar. Performing PCR and culture methods increased positivity as compared to performing them alone. In comparison with the PCR method, culturing in Fusobacterium selective agars had moderate sensitivity and low specificity for D. nodosus (71.7 and $28.7 \%$ ) and F. necrophorum $(61.3$ and $80.0 \%$ ), respectively. In conclusion, Fusobacterium selective agar (without antibiotics) for isolation and identification of D. nodosus is superior to Eugon agar. Fusobacterium necrophorum should also be considered as a provoking agent for footrot in small ruminants. The PCR method on culture increases elucidation of definitive aetiology.
\end{abstract}

Anaerobe agents, PCR, selective medium, sensitivity, specificity

Footrot is a contagious disease of sheep and goats, affecting the capsula ungulae and the interdigital region (Sagliyan et al. 2003; Sertkaya and Sindak 2004; Cagatay and Hickford 2006; Raadsma and Egerton 2013). Its mortality rate is reported to be $40 \%$, whereas its morbidity rate is highly variable $(8-100 \%)$ (Sagliyan 2003). The outbreak occurs mostly in wet seasons (Allworth 2004; Sertkaya and Sindak 2004) because the disease spreads via contacting mud and faeces as well as consuming roughages contaminated with purulent discharges in grasslands (Raadsma and Egerton 2013).

Dichelobacter nodosus and Fusobacterium necrophorum are the primary and secondary agents, respectively, when both are involved (Sagliyan et al. 2003; Sertkaya and Sindak 2004; Raadsma and Egerton 2013). Dichelobacter nodosus is a Gram negative, non-spore-forming rod, and obligate anaerobic bacterium (Garrity et al. 2005; Raadsma and Egerton 2013). Hoof agar, TAS (Trypticase arginine serine) agar and Eugon agar are suggested for its isolation (Stewart and Claxton 1982). Fimbria, protease, and elastase structures are known determinants of its virulence. The known D. nodosus virulence factors are its type IV fimbria and extracellular serine proteases (Garrity et al. 2005). Fusobacterium necrophorum is a Gram negative, non-spore-forming rod, and obligate anaerobic bacterium (Timoney et al. 1988).

Address for correspondence:

Seyda Cengiz, DVM, PhD.

Department of Microbiology

Faculty of Veterinary Medicine

Atatürk University, Erzurum 25240, Turkey
Phone: +90-442-231 5557

Fax: +90-442-236 8180

E-mail: seliberia@hotmail.com

http://actavet.vfu.cz/ 
Inflammation begins in the interdigital region and skin where capsule ungulae contacts at onset. Signs include hair loss in the region, sensitivity and reddishness of skin, and presence of serous exudate and necrosis in the neighbouring tissues. In severe cases, inflammation diffuses from the interdigital region to abaxial wall of capsulae ungulae. The hoof is affected by lesion and purulent exudate (Sagliyan et al. 2003). The degree of severity of the disease is based on the lesion intensity, which is as follows (Stewart and Claxton 1982):

Score 1; moderate inflammation causing erosion of interdigital skin epithelium,

Score 2; necrotic inflammation covering the interdigital region and partially or completely the axial wall of the hoof,

Score 3; necrotic inflammation extending to the abaxial wall of the hoof,

Score 4; hoof structure is disturbed due to lesion expanded to the abaxial wall,

Score 5; laminae and other soft tissues are necrotized.

Production loss, preventive measures, and treatment are very expensive (Raadsma and Egerton 2013). Wool/mohair, milk, body condition, body weight, and lambing losses are very critical (Sagliyan 2003; Sagliyan et al. 2003). Reports from the UK and Australia show that footrot cost 24 million pounds and 18.4 million dollars between 2005 and 2006, respectively (Dhungyel et al. 2013). The present experiment was conducted to determine the isolation and identification rates of D. nodosus and F. necrophorum in the culture techniques and to reveal the specificity and sensitivity of the culture technique based on the polymerase chain reaction (PCR) method in sheep with footrot.

\section{Materials and Methods}

Sample collection

The study was conducted on 83 sheep suspected with footrot based on clinical signs. Samples were collected using dry swabs and swabs with Amies medium. The ATCC 25549 D. nodosus and ATCC 25285 F. necrophorum were used as positive controls.

After consulting the State Agriculture Department between April and November 2013 about footrot occurrence as herd basis by provinces, samples were taken from sheep and goats exhibiting footrot greater than Score 2 using swabs with Amies medium for culture and sterile dry swabs for PCR analysis. Swabs were collected and stored at $4{ }^{\circ} \mathrm{C}$ for culture and at $-20{ }^{\circ} \mathrm{C}$ for PCR analysis.

\section{Bacteriology}

Samples were cultured on Eugon agar enriched with 5\% defibrinated sheep blood for isolation of D. nodosus and Fusobacterium selective agar (FSA) with 5\% defibrinated sheep blood and other components (i.e., hemin, tween 80, and dithioeritrol), but without antibiotic supplements (i.e., neomycin, josamycin, and vancomycin) for isolation of $D$. nodosus and $F$. necrophorum. Prior to culture these media were kept in jars along with a commercial kit (AnaeroGen ${ }^{\mathrm{TM}}$, Oxoid Ltd, Basingstoke, Hampshire, England) to provide anaerobiosis. Colonies were evaluated under a microscope (BX43, Olympus, Tokyo, Japan) after incubation at $37{ }^{\circ} \mathrm{C}$ for $3 \mathrm{~d}$ in terms of morphology, haemolytic properties, incubation needs, and Gram staining (Quinn et al. 2004). Colonies were then transferred to sterile $1.5 \mathrm{ml}$ tubes with sterile phosphate buffered saline (PBS) for PCR analysis.

DNA extraction of swab samples

The DNA was extracted from dry swabs using the DNA extraction kit (DNeasy Blood and Tissue kit, Qiagen, Hilden, Germany). Briefly, dry swabs were placed in sterile 1.5-ml tubes with sterile PBS and vortexed. A $100-\mu 1$ sample was used for DNA extraction according to the manufacturer's recommendations.

DNA extraction of bacterial cultures

Bacterial DNA was extracted from colonies using the DNA extraction kit. Colonies were collected from agar and suspended in sterile 1.5-ml tubes with sterile PBS. Colonies were thawed and vortexed. A 100- $\mu$ l sample was used for DNA extraction according to the manufacturer's recommendations. Primers specific to fimA gene region of D. nodosus and $l k t A$ gene region of F. necrophorum (Tables 1) were used in the PCR analysis (Cagatay and Hickford 2006; Bennett et al. 2009a).

Polymerase chain reaction

The mixture $(20 \mu \mathrm{l})$ for $D$. nodosus was prepared to contain each primer $(0.25 \mathrm{mM})$, each dNTP $(200 \mathrm{mM})$, DNA $(1 \mu \mathrm{l})$, Taq DNA polymerase (1 U), and PCR buffer. After a 2-min thermal cycle (TechneTC-5000, Thermo 
Scientific, UK) at $94{ }^{\circ} \mathrm{C}$ for 40 cycles, aliquots were processed at $94{ }^{\circ} \mathrm{C}$ for $30 \mathrm{~s}$ for denaturation, at $62{ }^{\circ} \mathrm{C}$ for 30 $\mathrm{s}$ for binding, at $72{ }^{\circ} \mathrm{C}$ for $50 \mathrm{~s}$ for elongation, and at $72{ }^{\circ} \mathrm{C}$ for $5 \mathrm{~min}$ for final elongation. Specimens were then placed in gel (1\%) and images were obtained in UV transilluminator (GL-500, Geneline, Giangarlo Scientific Co, Inc., Pittsburgh, PA). All samples of PCR amplification products $(10 \mu \mathrm{l})$ were subjected to electrophoresis. The DNA was visualized by UV fluorescence after staining with ethidium bromide. The PCR amplification products with $450 \mathrm{bp}$ were considered D. nodosus positive (Fig. 1) (Cagatay and Hickford 2006).

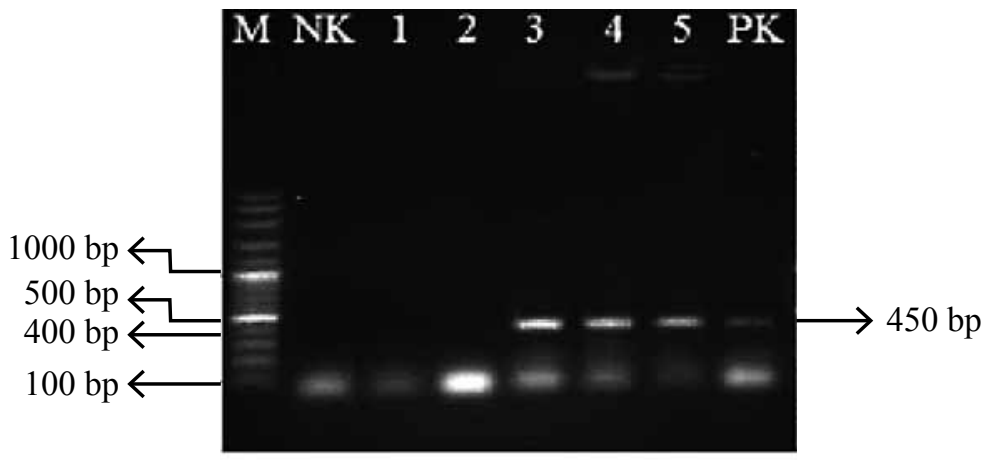

Fig. 1. Determination of D. nodosus in PCR. M: Marker (DNA Ladder Plus, Fermantas, Lithunia), NK: Negative control, 1-5: D. nodosus positive samples, PK: Positive control.

Similarly, the mixture $(20 \mu \mathrm{l})$ for $F$. necrophorum was prepared to contain each primer $(0.25 \mu \mathrm{M})$, each dNTP $(150 \mu \mathrm{M})$, extracted DNA $(1 \mu \mathrm{l})$, Taq DNA polymerase $(0.5 \mathrm{U})$, and PCR buffer. After a 5 -min thermal cycle at $94{ }^{\circ} \mathrm{C}$ for 35 cycles, aliquots were processed at $94{ }^{\circ} \mathrm{C}$ for $30 \mathrm{~s}$ for denaturation, at $59{ }^{\circ} \mathrm{C}$ for $30 \mathrm{~s}$ for binding, at $72{ }^{\circ} \mathrm{C}$ for $30 \mathrm{~s}$ for elongation, and at $72{ }^{\circ} \mathrm{C}$ for $5 \mathrm{~min}$ for final elongation. Specimens were then placed in gel $(1 \%)$ and images were obtained in UV transilluminator. All samples of PCR amplification products $(10 \mu \mathrm{l})$ were subjected to electrophoresis. DNA was visualized by UV fluorescence after staining with ethidium bromide. PCR amplification products with $400 \mathrm{bp}$ were considered F. necrophorum positive (Fig. 2) (Bennett et al. 2009a).

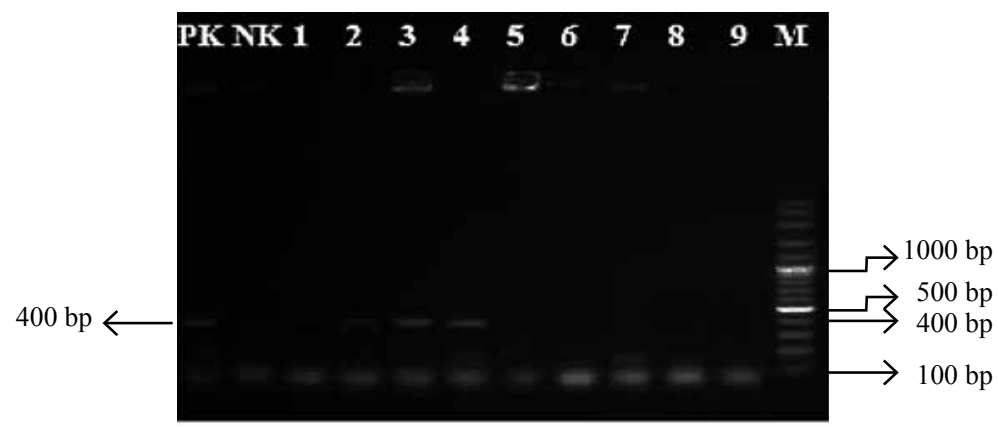

Fig. 2. Determination of F. necrophorum in PCR. M: Marker (DNA Ladder Plus, Fermantas, Lithunia), NK: Negative control, 1-9: F. necrophorum positive samples, PK: Positive control.

\section{Data analysis}

The frequency procedure was employed in data analysis to attain the isolation and identification rates by the culture technique. Moreover, receiver operating characteristic (ROC) curves were developed to determine the sensitivity (the ability to detect an ill animal), specificity (the ability to avoid detecting a healthy animal), positive likelihood ratio (low specificity or the odds of an ill animal when the test is positive), and negative likelihood 
ratio (low sensitivity or the odds of an ill animal when the test is negative) of culture diagnosis on PCR analysis (MedCalc Statistical Software version 13.1.2, Ostend, Belgium).

\section{Results}

All samples collected by sterile dry swabs were negative for D. nodosus, whereas 4 samples $(4.8 \%)$ were positive for F. necrophorum in PCR analysis.

All suspected samples cultured in Eugon agar were negative for D. nodosus in the PCR analysis. Among the suspected samples cultured in FSA, D. nodosus was positive in 46 samples $(55.4 \%)$ and $F$. necrophorum was positive in 58 samples $(69.8 \%)$ in the PCR analysis (Table 1). Both $D$. nodosus and $F$. necrophorum were negative and positive in 18 and 39 cultured samples, respectively. In 19 cultured samples, D. nodosus was negative, whereas $F$. necrophorum was positive. In 7 cultured samples, D. nodosus was positive,

Table 1. Primers specific to fimA gene region of $D$. nodosus and $l k t A$ gene region of $F$. necrophorum.

\begin{tabular}{|c|c|}
\hline Primer & Sequence \\
\hline \multicolumn{2}{|c|}{ D. nodosus (fimA gene) } \\
\hline \multicolumn{2}{|l|}{ Forward } \\
\hline U1 & 5' - ATCCCTGCATACAACGACTAC AT - 3' \\
\hline $\mathrm{U} 2$ & 5' - GCT ATT CCACAATACCAAAACTAC AT - 3' \\
\hline \multicolumn{2}{|l|}{ Reverse } \\
\hline D1 & 5' - ACT CAA GAG AGA GGCTTTTAAGTA AG - 3' \\
\hline D2 & 5’ - AGA GAG GCTTTCACATTTAAGAGC - 3’ \\
\hline D3 & 5’ - GTACCGAAGTACACCTTT GAT TG - 3’' \\
\hline \multicolumn{2}{|c|}{ F. necrophorum (lktA gene) } \\
\hline Forward & 5'-ACAATCGGAGTAGTAGGTTC - 3 \\
\hline Reverse & 5' - ATT TGGTAACTGCCACTG C - 3' \\
\hline
\end{tabular}

Table 2. PCR analysis of suspected samples cultured in FSA by the province.

\begin{tabular}{lcccccc}
\hline Province & $\begin{array}{c}\text { D. nodosus } \\
+\end{array}$ & $\begin{array}{c}\text { F.necrophorum } \\
+\end{array}$ & $\begin{array}{c}\text { D. nodosus } \\
\text { F.necrophorum }+\end{array}$ & $\begin{array}{c}\text { D. nodosus } \\
\text { F.necrophorum - }\end{array}$ & $\begin{array}{c}\text { D. nodosus }{ }^{+} \\
\text {F.necrophorum - }\end{array}$ & $\begin{array}{c}\text { D. nodosus - } \\
\text { F. necrophorum }+\end{array}$ \\
\hline A & 1 & - & 3 & 1 & 1 & - \\
B & - & 1 & - & 3 & - & 1 \\
C & - & 1 & - & 3 & - & 1 \\
D & 2 & 1 & 3 & - & 2 & 1 \\
E & - & 1 & - & 3 & - & 1 \\
F & 2 & - & - & 3 & 2 & - \\
G & - & - & - & 5 & - & - \\
H & 1 & 4 & 5 & - & 1 & 4 \\
I & - & 3 & - & - & - & 3 \\
J & - & 5 & 7 & - & - & 5 \\
K & - & 1 & 11 & - & - & 1 \\
L & 1 & 2 & 10 & - & 1 & 2 \\
& $46(55.4 \%)$ & $58(69.8 \%)$ & $39(46.9 \%)$ & $18(21.6 \%)$ & $7(8.4 \%)$ & $19(22.8 \%)$ \\
\hline
\end{tabular}

FSA - Fusobacterium selective agar 
whereas F. necrophorum was negative. Positivity for either bacterium in the PCR analysis was considered footrot (Table 2).

The sensitivity and specificity of FSA agar as compared to the PCR method were 71.7 and $28.7 \%$ for D. nodosus and 61.3 and $80.0 \%$ for F. necrophorum, respectively (Plate I, Fig. 3).

\section{Discussion}

While $D$. nodosus is the primary pathogen causing footrot, $F$. necrophorum invades the interdigital areas secondarily and eases a continuing invasion of $D$. nodosus. Therefore, the infection should occur through a synergistic action with F. necrophorum. Although culture is a common method for pathogen identification, bacteria causing footrot are obligate anaerobes, sensitive to dryness, requiring special medium, which makes the isolation and identification difficult, especially when the sampling site is contaminated with other pathogens (Rood et al. 1996; Bennett et al. 2009a; Tadepalli et al. 2009). Thus, enrichment of the medium to provide selectivity is critical for colony formation. Eugon agar enriched with 5\% sheep blood for isolation of D. nodosus and FSA for isolation of $F$. necrophorum are commonly used. However, Eugon agar is shown to be inefficient for isolating $D$. nodosus. Thus, addition of hemin, Tween-80, $\mathrm{Na}_{2} \mathrm{HPO}_{4}, \mathrm{KH}_{2} \mathrm{PO}_{4}, \mathrm{MgSO}_{4}$, and dithiothretiol to Brucella agar enhances colonization of anaerobic bacteria, which adversely affects colonization of aerobic bacteria (Nitzan et al. 1994; Noel et al. 2005). Tween-80 stimulates enzyme secretion based on the degree of bacterial cell wall permeability increase (Lee et al. 2003). Thus, we used FSA medium with hemin, Tween 80, $\mathrm{Na}_{2} \mathrm{HPO}_{4}$, $\mathrm{KH}_{2} \mathrm{PO}_{4}, \mathrm{MgSO}_{4}$, and dithiothretiol and without antibiotics (vancomycin, josamycin, neomycine) to isolate $D$. nodosus. Indeed, more D. nodosus was isolated from colonies in FSA than in Eugon agar, which could be attributed to the enrichment of agar with hemin and Tween 80 (Nitzan et al. 1994; Lee et al. 2003; Noel et al. 2005). For being specific to F. necrophorum, its isolation in FSA was easier than of D. nodosus (Morgenstein et al. 1981). However, there is lack of comparison with Eugon agar because only FSA was used for isolation of $F$. necrophorum.

Rood et al. (1996) conducted a typing on 771 frozen D. nodosus isolates in 4\% hoof and Eugon agars, followed by biochemical tests and reported difficulty in isolation and slow growth rate of $D$. nodosus in conventional methods. The PCR is a commonly used method for isolation and identification of a number of bacteria after culture, including D. nodosus and F. necrophorum (Ghimire et al. 1998; Moore et al. 2005; Zhou et al. 2010; Petrov and Dicks 2013). In a similar experiment, Cagatay and Hickford (2006) incubated swab samples in hoof agar and Eugon agar and performed PCR on suspected samples for $D$. nodosus fim $A$ region. In the present study, colonies grown on Eugon agar were negative for $D$. nodosus and those grown on FSA were positive for D. nodosus and F. necrophorum. These observations and PCR confirmations are in agreement with previous studies (Ghimire et al. 1998; Moore et al. 2005; Petrov and Dicks 2013). The positivity frequency is reported to be greater in the PCR analysis performed on cultured colonies than in the PCR analysis performed directly on dry swab samples (Ghimire et al. 1998; Moore et al. 2005; Cagatay and Hickford 2006; Petrov and Dicks 2013).

The PCR method is considered golden standard for bacterium identification. In the present study, despite being grown on FSA agar, sensitivity of culturing on FSA agar was moderate for $F$. necrophorum and $D$. nodosus. However, specificity of FSA agar was expectedly low. Identification of $F$. necrophorum and $D$. nodosus differs in the literature. Bennet et al. (2009b) examined 148 hoof samples and reported that positivity for $F$. necrophorum and D. nodosus was $53 \%(\mathrm{n}=79)$ and $5 \%(\mathrm{n}=7)$ in the PCR analysis employing lktA gene and fimA gene, respectively. Fusobacterium necrophorum and D. nodosus are considered 
primary and secondary causative agents for septic laminitis in cattle and sheep footrot. Petrov and Dicks (2013) conducted an experiment to verify the etiological role of $F$. necrophorum and D. nodosus in hoof thrush in horses. Out of 28 swab samples collected from 8 healthy horses and 8 horses with hoof thrush, there were colony formations in 6 samples ( 5 from affected horses and 1 from ahealthy horse). Biochemical tests revealed F. necrophorum subsp. necrophorum, F. necrophorum subsp. funduliforme, and F. equinum in colonies. However, PCR analyses for $l$ ktA and fimA gene regions showed positivity for Fusobacterium spp. in all colonies, but not for D. nodosus. They concluded that $F$. necrophorum, but not $D$. nodosus, was a causative agent for hoof thrush in horses.

In the experiment of Zhou et al. (2009), the positivity rate for $F$. necrophorum was $13 / 14,6 / 6$, and 9/9 swab samples collected from 14 sheep, 6 goats, and 9 cattle with septic laminitis using primers specific to $l k t A$ gene region in the PCR analysis. These suggest that F. necrophorum should also be considered a causative agent for footrot in small ruminants. Bennet et al. (2009c) examined samples from healthy goats and 24 goats with footrot by the PCR method. Healthy goats were negative for F. necrophorum and D. nodosus, whereas affected goats had positivity for D. nodosus $(62.5 \% ; 15 / 24)$ and F. necrophorum $(33.3 \%$, $8 / 24)$. Of the samples positive for $F$. necrophorum, 7 were also positive for $D$. nodosus (87.5\%). In another experiment by Bennet et al. (2009a), positivity for F. necrophorum was reported in one sample in 50 healthy sheep. All healthy sheep were negative for D. nodosus. In 17 samples from sheep with footrot $(\mathrm{n}=42)$, there was positivity for both F. necrophorum and D. nodosus. The positivity of one healthy animal was attributed to sampling from a contaminated region. Studies conducted in Kashmir, positivity for D. nodosus using the PCR analysis on swab samples was reported to be $54 \%(\mathrm{n}=370)$ (Rather et al. 2011) and 61\% $(n=200)$ (Bhat et al. 2012) in sheep with footrot.

In another study conducted in Germany with swab samples incubated on Eugon agar $(\mathrm{n}=13)$, the culture was positive in 11 samples, of which 6 were positive for $D$. nodosus in the PCR analysis (Zhou et al. 2010). A more comprehensive experiment was conducted by Moore et al. (2005) on 39 farms in England and Wales in 2000-2004. The researchers selected two healthy and six affected sheep from each farm, totalling samples from 77 healthy and 193 affected sheep. The positivity rate for D. nodosus was 11/77 in healthy sheep and 105/193 sheep with footrot. Of the collected samples, 263 were subjected to PCR analysis and culture, which showed positivity in 112 samples and negativity in 110 samples. In 39 samples, the PCR analysis was positive and the culture was negative. In 2 samples the PCR analysis was negative and the culture was positive. These figures suggest that PCR has $1 \%$ false-negative and $15 \%$ true-positive rates compared to culture, indicating superiority of the PCR method to the culture in agent identification. Our findings for D. nodosus (Moore et al. 2005; Bennett et al. 2009a; Rather et al. 2011) and F. necrophorum (Bennett et al. 2009a, 2009c; Zhou et al. 2009) were inconsistent with literature. Inconsistency may be caused by the severity of disease, involvement of other bacteria, sampling collection protocol, and the production system. Because the bacterium is an obligate anaerobe sensitive to environmental conditions and potential contamination of the sampling site, performing both culture and PCR analysis makes identification of $D$. nodosus and $F$. necrophorum more accurate than performing each of these methods alone. This approach helps determine the effective prevention and treatment programme (Zhou et al. 2009).

In summary, our data suggest that $F$. necrophorum should also be considered as a provoking agent for footrot in small ruminants in addition to D. nodosus. The use of enriched agar increases the isolation success of $D$. nodosus. The FSA agar has low sensitivity and specificity for detecting D. nodosus and F. necrophorum. Employment of the PCR method on culture could increase definitive aetiology, and consequently determination of effective protocols of prevention and treatment. 


\section{Acknowledgements}

This work was supported by the Ministry of Food, Agriculture and Livestock of the Republic of Turkey, General Directorate of Agricultural Researches and Policies (TAGEM) (project numbers TAGEM/ HSGYAD/13/ A07/P02/24). The authors wish to thank Mustafa Us, Omer Faruk Kucukkalem, Ismail Sahindokuyucu, Ufuk Dinler, and Senay Seyitoglu in the Erzurum Veterinary Control Institute for technical assistance and Dr. Armagan Hayirli at the Department of Animal Nutrition and Nutritional Diseases, Faculty of Veterinary Medicine, Atatürk University for data analysis and editing the manuscript.

\section{References}

Allworth B 2004: Footrot. In: Sheep medicine - Proceedings 355 Post Graduate Foundation in Veterinary Science University of Sydney, Sydney, pp. 227-253

Bennett G, HickfordJ, Sedcole R, Zhou H 2009a: Dichelobacter nodosus, Fusobacterium necrophorum and the epidemiology of footrot. Anaerobe 15: 173-176

Bennett G, Hickford J, Zhou H, Laporte J, Gibbs J 2009b: Detection of Fusobacterium necrophorum and Dichelobacter nodosus in lame cattle on dairy farms in New Zealand. Res Vet Sci 87: 413-5.

Bennett G, Loenen AV, Zhou H, Sedcole R, Hickford J 2009c: The detection of Dichelobacter nodosus and Fusobacterium necrophorum from footrot lesions in New Zealand goats. Anaerobe 15: 177

Bhat MA, Wani SA, Hussain I, Magray SN, Muzafar M 2012: Identification of two new serotypes within serogroup B of Dichelobacter nodosus. Anaerobe 18: 91-95

Cagatay IF, Hickford JGH 2006: Characterization of footrot bacteria Dichelobacter nodosus using PCR amplification and DNA sequence analysis. Turk J Vet Anim Sci 30: 53-59

Dhungyel O, Schiller N, Eppleston J, Lehmann D, Nilon P, Ewers A, Whittington R 2013: Outbreak-specific monovalent/bivalent vaccination to control and eradicate virulent ovine footrot. Vaccine 31: 1701-1706

Garrity GM, Bell JA, Lilburn T 2005: Dichelobacter spp., Cardiobacteriales, In: George GM, Staley JT, Boone DR, Brenner DJ, De Vos P, Garrity GM, Goodfellow M, Krieg NR, Rainey FA, Karl-Heinz Schleifer KH (Eds): Bergey's Manual of Systematic Bacteriology. Springer, New York, pp. 126-131

Ghimire SC, Egertonb JR, Dhungyel OP, Joshia HD 1998: Identification and characterization of serogroup M among Nepalese isolates of Dichelobacter nodosus, the transmitting agent of footrot in small ruminants. Vet Microbiol 62: 217-233

Lee SS, Ahn BH, Kim HS, Kim CH, Cheng KJ, Ha JK 2003: Effects of non-ionic surfactants on enzyme distributions of rumen contents, anaerobic growth of rumen microbes, rumen fermentation characteristics and performances of lactating cows. Asian-Aust J Anim Sci 16: 104-115

Moore LJ, Wassink GJ, Green LE, Grogono-Thomas R 2005: The detection and characterization of Dichelobacter nodosus from cases of ovine footrot in England and Wales. Vet Microbiol 108: 57-67

Morgenstein AA, Citron DM, Finegold SM 1981: New medium selective for Fusobacterium species and differential for Fusobacterium necrophorum. J Clin Microbiol 13: 666-669

Nitzan Y, Wexler HM, Finegold SM 1994: Inactivation of anaerobic bacteria by various photosensitized porphyrins or by hemin. Curr Microbiol 29: 125-131

Noel AR, Bowker KE, MacGowan AP 2005: Pharmacodynamics of moxiloxacin against anaerobes studied in an in vitro pharmacokinetic model. Antimicrob Agents Chemother 49: 4234-4239

Petrov KK, Dicks LMT 2013: Fusobacterium necrophorum, and not Dichelobacter nodosus, is associated with equine hoof thrush. Vet Microbiol 161: 350-352

Quinn PJ, Carter ME, Markey BK, Carter GR 2004: Non-spore-forming anaerobic bacteria. In Ouinn PJ (Ed.): Clinical Veterinary Microbiology. Mosby Press, London, pp. 184-190

Raadsma HW, Egerton JR 2013: A review of footrot in sheep: aetiology, risk factors and control methods. Livest Sci 156: 106-114

Rather MA, Wani SA, Hussain I, Bhat MA, Kabli ZA, Magray SN 2011: Determination of prevalence and economic impact of ovine footrot in central Kashmir India with isolation and molecular characterization of Dichelobacter nodosus. Anaerobe 17: 73-77

Rood JI, Howarth PA, Haring V, Billington SJ, Yong WK, Liu D, Palmer MA, Pitman DR, Links I, Stewart DJ, Vaughan JA 1996: Comparison of gene probe and conventional methods for the differentiation of ovine footrot isolates of Dichelobacter nodosus. Vet Microbiol 52: 127-141

Sagliyan A 2003: Clinical evaluation of sheep foot diseases observed in Elazığ region. Firat Univ Vet J Health Sci 17: 39-44

Sagliyan A, Gunay C, Koparir M 2003: The role of copper and zinc in the etiology of foot-rot of sheep in Elazığ region. Turk J Vet Surg 9: 11-16

Sertkaya H, Sindak N 2004: Incidence and treatment with two different drug combinations of sheep's footrot in Birecik District of Şanlıurfa and its villages. Turk J Vet Surg 10: 48-54

Stewart DJ, Claxton PD 1982: Ovine footrot clinical diagnosis and bacteriology. In: Corner, LA, Bagust TJ (Eds): Australian Standard Diagnostic Techniques for Animal Diseases, CSIRO Information Services, Melbourne, pp. 1-27 
Tadepalli S, Narayanan SK, Stewart GC, Chengappa MM, Nagaraja TG 2009: Fusobacterium necrophorum: a ruminal bacterium that invades liver to cause abscesses in cattle. Anaerobe 15: $36-43$

Timoney JF, Gillespie JH, Scott FW, Barlough JE 1988: The Genera Fusobacterium and Bacteroides In: Timoney JF, Gillespie JA, Scott FW, Barlough JE (Eds): Hagan and Bruner's Microbiology and Infectious Diseases of Domestic Animals. Cornell University Press. New York. pp. 161-170

Zhou H, Bennett G, Hickford J 2009: Variation in Fusobacterium necrophorum strains present on the hooves of footrot infected sheep, goats and cattle. Vet Microbiol 135: 363-267

Zhou H, Lottner S, Ganter M, Hickford JGH 2010: Identification of two new Dichelobacter nodosus strains in Germany. The Vet J 184: 115-117 
Plate I

Cengiz S. et al.: Isolation and identification ... pp. 97-104
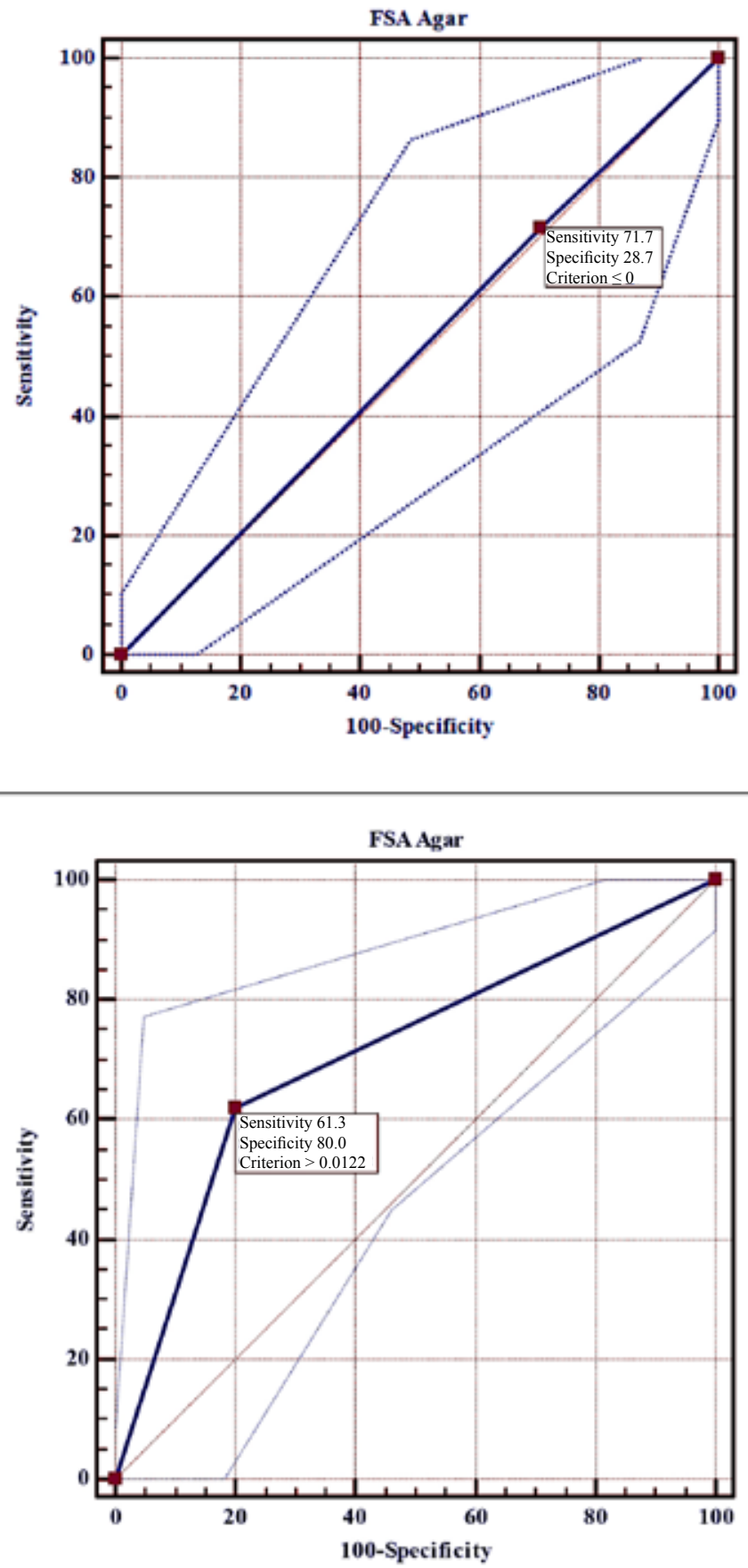

Fig. 3. Sensitivity and specificity of Fusobacterium selective agar for culturing D. nodosus (upper panel) and $F$. necrophorum (lower panel) as compared to the PCR method. 